\title{
Correction to: Verification of randomized consensus algorithms under round-rigid adversaries
}

\author{
Nathalie Bertrand ${ }^{1} \cdot$ Igor Konnov ${ }^{2} \cdot$ Marijana Lazić $^{3} \cdot$ Josef Widder $^{2}$
}

Published online: 30 May 2021

(c) The Author(s) 2021

\section{Correction to: \\ International Journal on Software Tools for Technology Transfer \\ https://doi.org/10.1007/s10009-020-00603-x}

The article Verification of randomized consensus algorithms under round-rigid Adversaries, written by Bertrand, N., Konnov, I., Lazić, M. and Widder, J., was originally published electronically on the publisher's internet portal on 2 February 2021 without open access. With the author(s)' decision to opt for Open Choice the copyright of the article changed on 7 April 2021 to $($ ) The Authors 2021 and the article is forthwith distributed under a Creative Commons Attribution Attribution 4. 0 International License, which permits use, sharing, adaptation, distribution and reproduction in any medium or format, as long as you give appropriate credit to the original author(s) and the source, provide a link to the Creative Commons licence, and indicate if changes were made. The images or other third party material in this article are included in the article's Creative Commons licence, unless indicated otherwise in a credit line to the material. If material is not included in the article's Creative Commons licence and your intended use is not permitted by statutory regulation or exceeds the permitted use, you will need to obtain permission directly from the copyright holder. To view a copy of this licence, visit http://creativecommons. org/licenses/by/4.0.

Open Access This article is licensed under a Creative Commons Attribution 4.0 International License, which permits use, sharing, adaptation, distribution and reproduction in any medium or format, as long as you give appropriate credit to the original author(s) and the source, provide a link to the Creative Commons licence, and indicate if changes were made. The images or other third party material in this article are included in the article's Creative Commons licence, unless indicated otherwise in a credit line to the material. If material is not included in the article's Creative Commons licence and your intended use is not permitted by statutory regulation or exceeds the permitted use, you will need to obtain permission directly from the copyright holder. To view a copy of this licence, visit http://creativecommons.org/licenses/by/4.0/.

Publisher's Note Springer Nature remains neutral with regard to jurisdictionalclaims in published maps and institutional affiliations.
The original article can be found online at https://doi.org/10.1007/ s10009-020-00603-x.

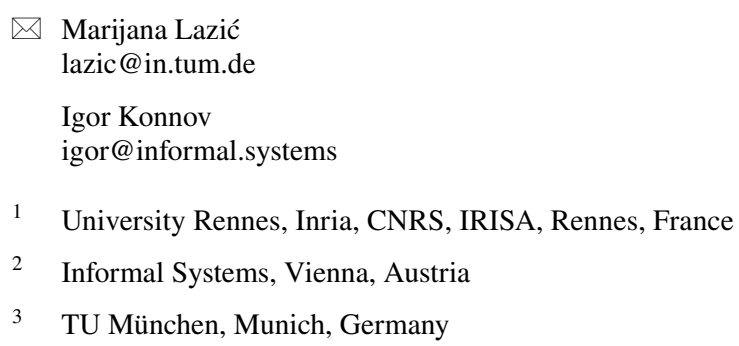

